\title{
WORKING
}

paper

\section{Stabilising virtues of central banks: (re)matching bank liquidity}

\author{
Vincent Legroux ${ }^{1}$, Imène Rahmouni-Rousseau ${ }^{2}$, \\ Urszula Szczerbowicz ${ }^{3} \&$ Natacha Valla $^{4}$
}

\author{
March 2018, WP \#667
}

\begin{abstract}
The liquidity of financial system plays a central role in systemic crises. In this paper, we show that the ECB haircut policies provided an important liquidity support to distressed financial institutions during the euro area sovereign debt turmoil. Using novel, micro data on the pool of collateral eligible to ECB open market operations, we construct a "public" liquidity mismatch indicator (LMI) for the French aggregate banking sector based on the ECB haircuts. We then compare it to the "private" LMI based on the haircuts in private repo markets in a spirit of Bai et al. (2018). The difference between the two indicators represents a new measure of the ECB liquidity support. Our results suggest that the ECB haircut policies have indeed helped French banks to reduce the liquidity mismatch. ${ }^{5}$
\end{abstract}

Keywords: Bank liquidity, liquidity mismatch, monetary policy, central bank, haircuts, collateral framework

JEL classification: E58; G21; G28

\footnotetext{
${ }^{1}$ Banque de France, vincent.legroux@banque-france.fr

${ }^{2}$ Banque de France, imene.rahmouni-rousseau@banque-france.fr

${ }^{3}$ Banque de France, urszula.szczerbowicz@,banque-france.fr

${ }^{4}$ European Investment Bank, n.valla@eib.org

${ }^{5}$ We thank Régis Breton, Leonardo Gambacorta (discussant), Luca Gattini, Benoît Nguyen, as well as the participants of the ACPR scientific committee meeting, Banque de France seminar, 2017 Irish Economic Association annual conference and 2017 FINEST Conference for helpful comments and suggestions. We are grateful to Benoit Nguyen for sharing the data on pool of eligible collateral.
}

Working Papers reflect the opinions of the authors and do not necessarily express the views of the Banque de France or the European Investment Bank. This document is available on publications.banque-france.fr/en 


\section{NON-TECHNICAL SUMMARY}

During the recent financial crisis the central banks implemented several measures to ease money market tensions and improve interbank liquidity conditions. In this paper, we look beyond the much researched impact of monetary policy on market-wide liquidity and concentrate on liquidity within banks' balance sheets. Using novel, micro data on the pool of eligible collateral in the ECB open market operations (OMO), we construct a "public" liquidity mismatch index (LMI) for the French banking sector. The novelty of our approach consists in accounting for the ECB's influence on bank liquidity and in particular in considering the effects of the ECB collateral and haircut policies.

LMI evaluates the mismatch between the market liquidity of assets and the funding liquidity of liabilities. More specifically, on the asset side we assume that in case of liquidity stress the bank reacts by maximizing the liquidity it can raise from its assets by pledging it as collateral at the OMO operations. The ECB haircuts define the amount of cash the bank can raise using its securities and loans as collateral. On the liability side, we assume that all of bank's creditors extract the maximum liquidity allowed under the terms of their contract as in Bai et al. (2018). The LMI is the difference between the asset-side liquidity and the liability-side liquidity. As both parts are expressed in terms of euros, it gives the "cash equivalent value" of a bank in a spirit of Brunnermeier et al. (2011).

The use of the ECB haircuts is an important difference with respect to Bai et al. (2018) who measure the liquidity mismatch of the US banking sector using private markets haircuts. We argue that the ECB haircuts are often smaller than these applied by the private repo market which gives the banks incentives to use their assets as collateral at OMO rather than in the private repo markets.

We calculate the LMI for individual French banks representing $87 \%$ of banking system total assets and then aggregate it for the whole banking system. When the aggregate LMI is low, the banking sector is more susceptible to a liquidity stress. The evolution of the banking system's liquidity mismatch between 2011 and 2015 is displayed on the Figure below.

\section{Liquidity mismatch index (LMI) of the French banking system}

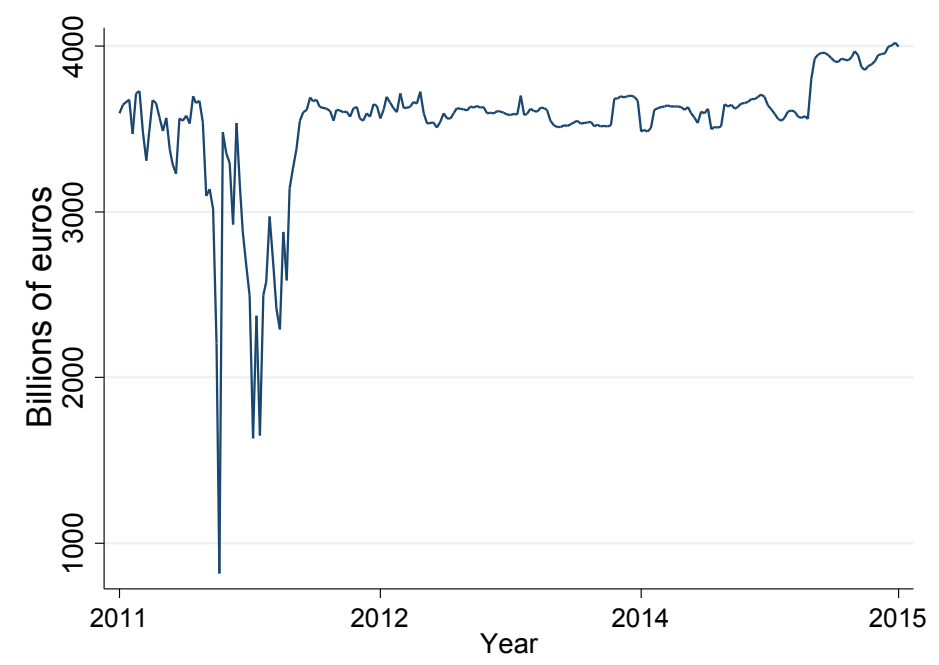

Note: A decrease in the LMI depicts a deterioration of the liquidity situation of the sector, i.e., an increase in the liquidity mismatch between assets and liabilities. Source: authors' computations. 
It provides a number of policy-relevant results. First, the French banking system was still afloat prior to the 2011 central bank interventions. In the second half of 2011 the liquidity mismatch for the system as a whole shows a drastic decline, suggesting a rapid worsening in systemic vulnerability following the stress episodes. Yet, the LMI never falls in negative territory, which demonstrates the resilience of the sector, in aggregate, to deteriorating funding conditions both on the asset and liability side. Moreover, the aggregated LMI of all banks in absolute terms stands at a higher level at the end of the 2015 than before the 2011 liquidity shock. Most importantly, the aggregated LMI increases notably towards the end of the period, starting in end 2014, and manages to exceed its initial level. This could reflect the impact of the planned implementation of the liquidity regulation, and in particular the Liquidity Coverage Ratio, which observation period was scheduled to start in 2015. Finally, the resilience of the system taken as a whole hides heterogeneity across counterparties. Some banks exhibit a lower LMI throughout the period and one bank stands out as an outlier, experiencing a dramatic fall of its LMI in 2011. The LMI can therefore help identify the individual French institutions that are fragile in terms of their liquidity exposures.

An alternative for the French banks would be to pledge their assets as collateral in private repo markets. We therefore construct an alternative LMI using the central clearing counterparty haircuts for sovereign bonds according to their maturity and country of issuance. We also account for the possibility that bank loans and some investment securities cannot be posted as collateral in private repo markets while they can be used as collateral at the OMOs of the ECB. We then compare the public LMI based on the ECB haircuts with the LMI based on private haircuts in repo markets. We show that the private LMI is consistently lower than public LMI which confirms that the ECB collateral and haircut policies have indeed alleviated banks' liquidity mismatch. If the banks were subject to higher private haircuts their liquidity would be reduced in a similar way as withdrawing of deposits. It could even lead to fire-sales of assets in time of financial stress. As such, the difference between public and private LMIs represents a proxy for the ECB liquidity support to the French banking system. In 2012, this support approached $€ 800$ billion.

\section{Les capacités stabilisantes des banques centrales : renforcer la liquidité bancaire}

La liquidité du système financier joue un rôle central dans les crises systémiques. Dans cet article, nous montrons que les politiques de décote de la BCE ont apporté un soutien important aux institutions financières durant la crise de la zone euro. En utilisant les nouvelles données sur le pool de collatéral éligible aux opérations de refinancement avec l'Eurosystème, nous construisons un indicateur de mismatch des liquidités (LMI) pour le secteur bancaire français basé sur les décotes de la BCE. Nous le comparons ensuite au LMI construit avec les décotes du marché repo privé, dans l'esprit de Bai et al. (2018). La différence entre les deux indicateurs représente une nouvelle mesure de soutien en liquidités de la BCE. Nos résultats suggèrent que les politiques de décote de la $\mathrm{BCE}$ ont en effet aidé les banques françaises à réduire le mismatch des liquidités.

Mots-clés : Liquidité bancaire, asymétrie de liquidité, politique monétaire, banque centrale, décote

Les Documents de travail reflètent les idées personnelles de leurs auteurs et n'expriment pas nécessairement la position de la Banque de France ou de la Banque européenne d'investissement. Ce document est disponible sur publications.banque-france.fr 


\section{Introduction}

Central banks play an important role in supporting overall market liquidity. During the recent financial crisis they implemented several conventional and unconventional monetary measures to ease money market tensions and improve interbank liquidity conditions. In this paper, we look beyond the much researched impact of monetary policy on market-wide liquidity and concentrate on liquidity within banks' balance sheets. Using novel, micro data on the pool of eligible collateral in the ECB open market operations (OMO), we construct a "public" liquidity mismatch index (LMI) for the French banking sector. The novelty of our approach consists in accounting for the ECB's influence on bank liquidity and in particular in considering the effects of the ECB collateral and haircut policies. Collateral and haircut policies have been less studied than interest rates policy and yet they are essential for the correct functioning of the monetary and financial systems (Bindseil et al. (2017)).

To construct the public LMI we expand on the papers of Brunnermeier et al. (2011)'s theoretical measure called "Liquidity Mismatch Index" which is defined as the difference between market liquidity of assets and funding liquidity of liabilities. ${ }^{1}$ Bai et al. (2018) further develop the LMI's concept and implement it to gauge the liquidity mismatch of the US bank holding companies during 2002 - 2014. The LMI jointly accounts for asset and liability liquidity based on bank balance sheet information and market measures of liquidity. It evaluates bank liquidity position under a stress scenario assuming that all of its creditors extract the maximum liquidity allowed under the terms of their contract, and that the bank reacts by maximizing the liquidity it can raise from its assets. When the aggregate LMI is low, the banking sector is more susceptible to undergo a liquidity stress.

This paper brings three contributions to this literature. First, it applies the LMI to a new, micro, dataset on the French banking sector. We calculate the index for individual French banks between 2011 and 2015 and then aggregate it for the whole banking system. LMI gives the "cash equivalent value" of the French banking sector and indicates the amount of further liquidity support that the ECB might have to provide in case of prolonged liquidity stress. Second, our public LMI takes into account the impact of the central bank haircut scheme on the banking sector liquidity. Bai et al. (2018) use market haircuts to define the amount of cash the bank can raise using its securities and loans as collateral. Here, we use the ECB haircuts and argue that they are relevant for the European banks liquidity mismatch for several reasons. Indeed, the haircuts applied by the ECB are often smaller than these applied by the private repo market which gives the banks incentives to use their assets as collateral at OMO rather than in the private repo markets. Moreover, in the fixed-rate fullallotment framework, the access to the ECB liquidity is limited only by the amount of eligible collateral that the bank holds. An additional reason to use ECB haircuts is that, unlike the Federal Reserve (Fed), the ECB accepts loans to non-financial corporations and public-sector entities as collateral which makes its haircuts on loans important for the bank liquidity assessment. Our final

\footnotetext{
${ }^{1}$ Market liquidity of assets refers to the ease to sell an asset without causing drastic changes in its price, while funding liquidity reflects the ability to settle obligations with immediacy.
} 
contribution is to compare public LMI based on the ECB haircuts to the private LMI based on repo market haircuts in a spirit of Bai et al. (2018). The difference between the two indicators is a novel measure of the ECB liquidity support.

Our analysis of the public LMI indicates that despite a rapid worsening in systemic vulnerability following the stress episodes in 2011, the LMI never falls in negative territory, which demonstrates the resilience of the French banking sector, in aggregate, to deteriorating funding conditions both on the asset and liability side. However, the resilience of the system taken as a whole hides heterogeneity across counterparties as some banks exhibit a lower LMI throughout the period with one bank falling into negative territory. The analysis also suggests that the ECB has alleviated banks' liquidity mismatch by a fair bit between 2011 and 2015. ${ }^{2}$ The recovery of the LMI between July 2011 and the beginning of February 2012 coincides with important ECB unconventional monetary measures and indicates that the ECB measures played an important role in the bank liquidity mismatch decrease. Finally, the aggregated LMI increases notably towards the end of the period, starting in end 2014, and manages to exceed its initial level. This could reflect the impact of the planned implementation of the liquidity regulation, and in particular the Liquidity Coverage Ratio, which observation period was scheduled to start in 2015.

We then compare the public LMI based on the ECB haircuts with the private LMI based on private haircuts in repo markets. We show that private LMI is consistently lower than public LMI which confirms that the ECB collateral and haircut policies have indeed alleviated banks' liquidity mismatch. If the banks were subject to higher private haircuts their liquidity would be reduced in a similar way as withdrawing of deposits. It could even lead to fire-sales of assets in time of financial stress.

The reminder of the paper is organised as follows. The next section discusses the impact of the ECB collateral and haircut policies on bank liquidity. Section 3 presents the public LMI. Section 4 shows the results for the French banking sector and compares public LMI to private LMI. Section 5 concludes.

\section{ECB's collateral and haircut policies have been key to bank liquidity}

One of the ECB's main goals is to provide liquidity to the financial system so as to preserve its stability. Conventionally, OMOs are sufficient tools to attain this objective. However, at the onset of the subprime crisis significant tensions appeared on the euro area interbank market putting in danger its financial stability. Indeed, the liquidity-constrained banks often hoard liquidity for precautionary reasons and are at the same time compelled to proceed to fire sales of assets,

\footnotetext{
${ }^{2}$ Here, we focus on the impact of the central bank haircut policy on bank liquidity. Berger and Bouwman (2017) study the impact of the interest rate policy on bank liquidity creation and find that it has very little effects on medium and large bank liquidity creation during both normal times and crises. Barthélemy et al. (2018) assess the impact of the ECB eligible collateral expansions on the valuation of eligible collateral and find that these policies improved the euro area banks' access to central bank money.
} 
affecting negatively their prices and the corresponding haircuts (Ewerhart and Valla, 2007). The ECB reacted very promptly to the tensions on the interbank market and implemented several unconventional monetary policy measures, such as exceptional liquidity provisions and collateral rules and haircut adjustment. ${ }^{3}$

The ECB collateral and haircut policies are the most relevant for our liquidity mismatch indicator. Since the creation of the euro area the ECB collateral framework was much less restrictive than the one in the United States. In particular, unlike the Fed, the ECB accepts financial institutions' loans as collateral. Euro area banks can therefore use them to satisfy their liquidity needs. Given that the secondary market for loans in the euro area is not well developed, the haircuts applied on the mobilisation of loans are important for bank liquidity assessment. The ECB haircut policies also played an essential role during the recent financial crisis as they impose an upper limit to the quantity of money that a central bank will supply in collateralised, monetary policy operations. After the Lehman Brothers collapse, the ECB significantly changed the level of haircuts and the way it applied them to riskier securities. In October 2008 it lowered the credit threshold that distinguishes between marketable and non-marketable assets from A- to BBB- ${ }^{4}$ In April 2010 the ECB decided to apply a schedule of graduated valuation haircuts to the assets rated in the BBB+ to BBB- range. This graduated haircut schedule replaced the uniform haircut add-on of $5 \%$ that had been applied to these assets previously. Chart 1 depicts the haircut on Italian and Portuguese sovereign bonds of maturity between five and ten years in the period between 2011 and 2015. In October 2013 the ECB raised the haircuts on low quality assets ( $B B B+$ to $B B B-$ ) while reducing them for the high quality assets (AAA to $A-$ ). In this way, the central bank allowed banks to obtain more liquidity with highquality assets, such as Italian sovereign bonds, and diminished further the amount of liquidity that could be raised with low-quality assets, such as Portuguese bonds. Indeed, in May 2011, the Portuguese sovereign bonds changed the credit category from high-credit to low-credit quality, which raised the haircut applied to these assets by 5 percentage points. The Italian bonds on the other hand were classified as high credit quality bonds in the OMO over the whole period. ${ }^{5}$ These changes in the haircut schedule had an immediate impact on the amount of liquidity that the banks could claim against their collateral. Moreover, the ECB decisions whether to maintain an asset within its actual credit category, downgrade it or suspend it from the OMO eligibility have also direct implications for the banks' liquidity mismatch.

\footnotetext{
${ }^{3}$ See Szczerbowicz (2015) for the detailed description of the unconventional monetary measures taken until 2013 and Marx et al. (2016) for the measures implemented later on.

${ }^{4}$ This rule did not apply to asset backed securities.

${ }^{5}$ On January 13, 2017, the DBRS downgraded Italy's sovereign credit rating to BBB (high). Of the four agencies used by the ECB to determine collateral requirements, DBRS was the only one that gave Italy an A-band rating so the downgrade means that the banks will be able to claim smaller amount of funds against the Italian bonds they hold. For instance, Italian bonds with the residual maturity between 7 and 10 years are now subject to $11,5 \%$ haircut compared to $3 \%$ applied previously.
} 


\section{Chart 1: ECB haircuts applicable to Italian and Portuguese sovereign bonds}

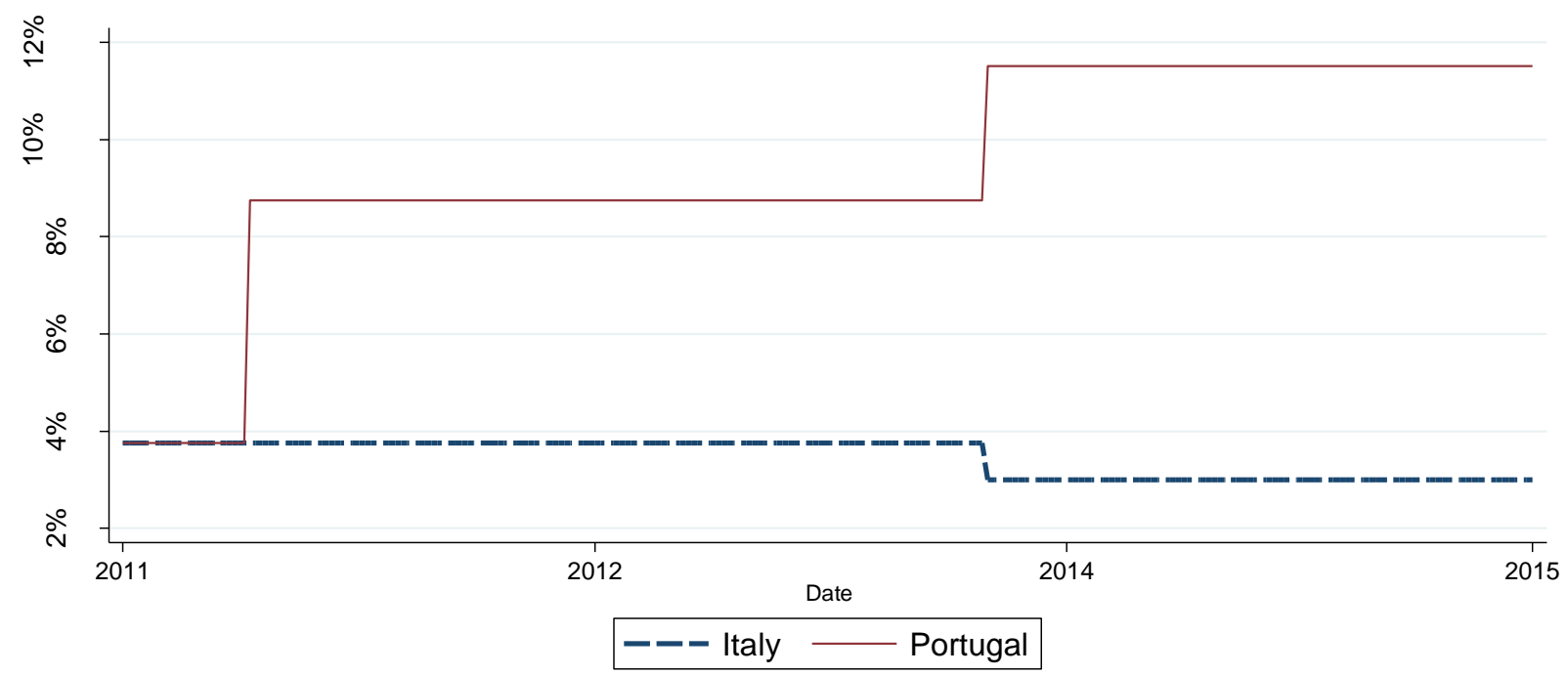

Note: Haircuts applied by the ECB to Italian and Portuguese sovereign bonds of maturity comprised between 5 and 10 years. Source: ECB website.

While the ECB haircuts evolved with financial market conditions, they were lower than haircuts applied by the private markets. Table 1 compares the ECB haircuts with those applied by LCH S.A., a central clearing counterparty, for the French and Italian sovereign bonds as of December 27, 2013. While the ECB applies the same haircuts for both French and Italian bonds, the private market haircuts are substantially lower for the French bonds. In what follows, we construct a public LMI based on the ECB haircuts and compare it to its private counterpart based on LCH haircuts in the subsequent section.

Table 1: Comparison of the ECB and LCH haircuts

\begin{tabular}{|l|l|l|}
\hline France & ECB haircut & LCH haircut \\
\hline $1-3$ year government bond & $\begin{array}{l}\text { Fixed coupon /Zero coupon } \\
\text { 1\% / } \%\end{array}$ & $1.25 \%$ \\
\hline $5-7$ year government bond & $2 \% / 3 \%$ & $3 \%$ \\
\hline $7-10$ year government bond & $3 \% / 4 \%$ & $3.5 \%$ \\
\hline$>10$ year government bond & $5 \% / 7 \%$ & $6.25 \%(10-15 y) ; 15 \%(15-30 y) ; 20 \%(>30 y)$ \\
\hline Italy & Fixed coupon / Zero coupon & \\
\hline $1-3$ year government bond & $1 \% / 2 \%$ & $18.75 \%$ \\
\hline $5-7$ year government bond & $2 \% / 3 \%$ & $22.75 \%$ \\
\hline $7-10$ year government bond & $3 \% / 4 \%$ & $24.5 \%$ \\
\hline$>10$ year government bond & $5 \% / 7 \%$ & $24.75 \%(10-15 y) ; 33.25 \%(>15 y)$ \\
\hline
\end{tabular}

Note: LCH S.A. haircuts as of December 27, 2013 and the corresponding ECB haircut schedule. Source: ECB website and LCH S.A. 


\section{Public liquidity mismatch indicator}

In this section we construct a public LMI that takes into account the role of the central bank collateral and haircut policy. As in Bai et al. (2018) our LMI evaluates the liquidity of a bank under a liquidity stress event that has a changing time horizon. It is constructed from both asset and liability side of the balance sheet but is also dependent on market indicators of liquidity premia. Each asset and liability category contributes to the liquidity position of the bank. They are assigned respectively positive or negative weights. The asset-side liquidity weights are partly calibrated and partly driven by the ECB haircuts of underlying securities and loans, while the liability-side weights are determined by liabilities' maturity structure and by the expected stress duration, which is pinned down by market liquidity premium. The LMI assumes that in a liquidity stress episode, all contractual claimants on the bank act to maximally extract cash from the bank. This means that overnight debt holders refuse to rollover debt and the bank has to cover the cash shortfall from this loss of funding.

More formally, the LMI for a bank $i$ at a given time $t$ is the net of the asset and liability liquidity, given by

$$
L M I_{t}^{i}=\sum_{k} \lambda_{t, a_{k}} a_{t, k}^{i}+\sum_{k^{\prime}} \lambda_{t, l_{k}} l_{t, k^{\prime}}^{i}
$$

where $a_{t, k}^{i}$ and $l_{t, k}^{i}$, represent respectively the value of class $k$ asset and class $k^{\prime}$ liability in bank $i$. $\lambda_{t, a_{k}}$ and $\lambda_{t, l_{k \prime}}$ are corresponding liability-side and asset-side liquidity weights comprised in the $\langle 0,1\rangle$ interval. Asset-side liquidity weights are positive and liability-side liquidity weights are negative. Therefore, the LMI is the difference between the asset-side liquidity and the liability-side liquidity. As both parts are expressed in terms of euros, it gives the "cash equivalent value" of a bank in a given state.

\subsection{Asset liquidity weights}

Computing the asset liquidity weights is a central point of our measure. The exact specification is as follows

$$
\lambda_{t, a_{k}}=1-m_{t, k}
$$

with $m_{t, k}$ corresponding to the haircut applied to the bank's $i$ class of asset $k$.

The balance sheet data obtained from Bloomberg allow us to distinguish the following classes of assets: cash and near cash items, interbank assets, short-term and long-term investments, net loans, net fixed assets, and other assets. Moreover, we obtain from EBA the quantities of sovereign bonds held by each bank differentiated by time to maturity and country of issuance. The asset liquidity weights define the amount of cash that a bank can raise over a short-term horizon for a given asset. We use the ECB haircuts as weights for loans, sovereign bond holdings and other security 
investments, and then calibrate the liquidity weights for the remaining asset categories. For cash and near cash items, interbank assets, which are very liquid, we set $\lambda_{t, a_{k}}=0.99$. For net fixed assets and other assets, which are difficult or time-consuming to convert into liquid funds, we set $\lambda_{t, a_{k}}=0$. This means that a bank that holds $100 €$ of interbank assets will be able to raise $\lambda_{t, a_{k}}=100 €$ in case of stress event while a bank that holds only fixed assets $\lambda_{t, a_{k}}=0$.

Bai et al. (2018) compute the haircuts for banks' securities based on the repo market haircuts and the loan haircuts based on the average bid price in the secondary loan market. The novelty of our approach consists in the use of the ECB haircuts to construct the weights for the bank loans and the bank security investments, including sovereign bond holdings. Therefore, we measure $\lambda_{t, a_{k}} a_{t, k}^{i}$ as the amount of cash the bank can immediately rise using $a_{t, k}^{i}$ as collateral at the ECB OMO to cover its liquidity outflows. The weights for these asset categories vary over time given that the ECB haircuts schedule and the credit quality of an asset change with market conditions.

ECB haircuts are relevant for the banks liquidity mismatch for a number of important reasons. First, the haircuts applied by the ECB can be smaller than these applied by the private repo market. This difference gives banks a clear incentive to mobilise these assets as collateral at the ECB operation rather than in private repo markets. Second, in the fixed-rate full-allotment framework, the only limit to access ECB is in fact the amount of eligible collateral that the bank holds. As a result, banks extensively used Eurosystem OMO operations to exchange their assets for the highly liquid central bank money, thereby offloading liquidity risk they were exposed to onto the central bank balance sheet. Finally, unlike private repo markets, the ECB also accepts non-marketable loans to nonfinancial corporations and public-sector entities as collateral. The ECB haircut on loans is therefore key to determine whether the assets of a bank are fully encumbered - and therefore how close a bank may be from the "fire sale" point.

\subsection{Liability liquidity weights}

Regarding liability liquidity weights, we follow Bai et al. (2018)'s theoretical and empirical approach. They show that the LMI today is the appropriately "discounted" value of the expected LMI tomorrow where the discount rate is the time-varying probability that the stress episode continues for a given period of time. In other words, at each period of time LMI is computed with different time horizon of liquidity stress. A time dimension of the LMI is an important feature of their approach. They solve a dynamic optimization problem for a bank that leads to an explicit specification of the liquidity weights as a function of liability's maturity and the expected duration of the liquidity stress. It is quite intuitive that these two characteristics matter for the liquidity measurement. Indeed, an overnight LMI that assumes that only overnight debt is not rolled over will be quite different to 30 day LMI that assumes that all liabilities maturing in the next 30 are not rolled over. Given that any fixed liquiditystress horizon can be considered arbitrary we adopt Bai et al. (2018) liquidity-stress horizon that 
allows for time-varying probability of the stress duration. More specifically, the liability liquidity weight coming from their dynamic optimization setting is an exponential function of the expected duration of the stress event and the liability's time to maturity such that:

$$
\lambda_{t, l_{k \prime}}=-\exp \left(-\mu_{t} T_{k^{\prime}}\right)
$$

where $\mathrm{T}_{\mathrm{k}^{\prime}}$ stands for the time-to-maturity of the liability class $k^{\prime}$ and $\mu_{\mathrm{t}}$ is an expected duration of the stress event.

The advantage of this formulation is that is allows to incorporate the time-varying probability of the stress duration. It is less clear from the empirical point of view what would be the best proxy for the expected stress duration. Bai et al. (2018) relate the liquidity stress-horizon to market liquidity conditions. First of all, they show that there is a relation between $\mu_{t}$ and the liquidity premium that the bank earns on its liabilities. They also argue that the bank liquidity premium can be approximated by the term structure of the OIS-TBill spread. ${ }^{6}$ Therefore we use the OIS-German Treasury Bill spread as an approximation of the expected duration of the stress event, $\mu_{t}$. Under the assumption that OISGerman TBill spread is a pure measure of the liquidity premium, as it is not contaminated by credit risk premium, $\mu_{t}$ is equal to $-\ln \left(\mathrm{OIS}-\mathrm{TB}\right.$ ill). ${ }^{7}$ OIS-German Tbill spread was equal to 0.1 on average in 2013, and equal to 0.6 in October 2011. In normal times the OIS-German TBill spread is small and therefore only the very short-term liabilities have high weights (Chart 2). In a liquidity crisis, when the OIS-German TBill spread is high, many types of liabilities have large weights except for the very long-duration securities such as equity.

Chart 2: Liability liquidity weights for maturities up to one year and up to ten years.
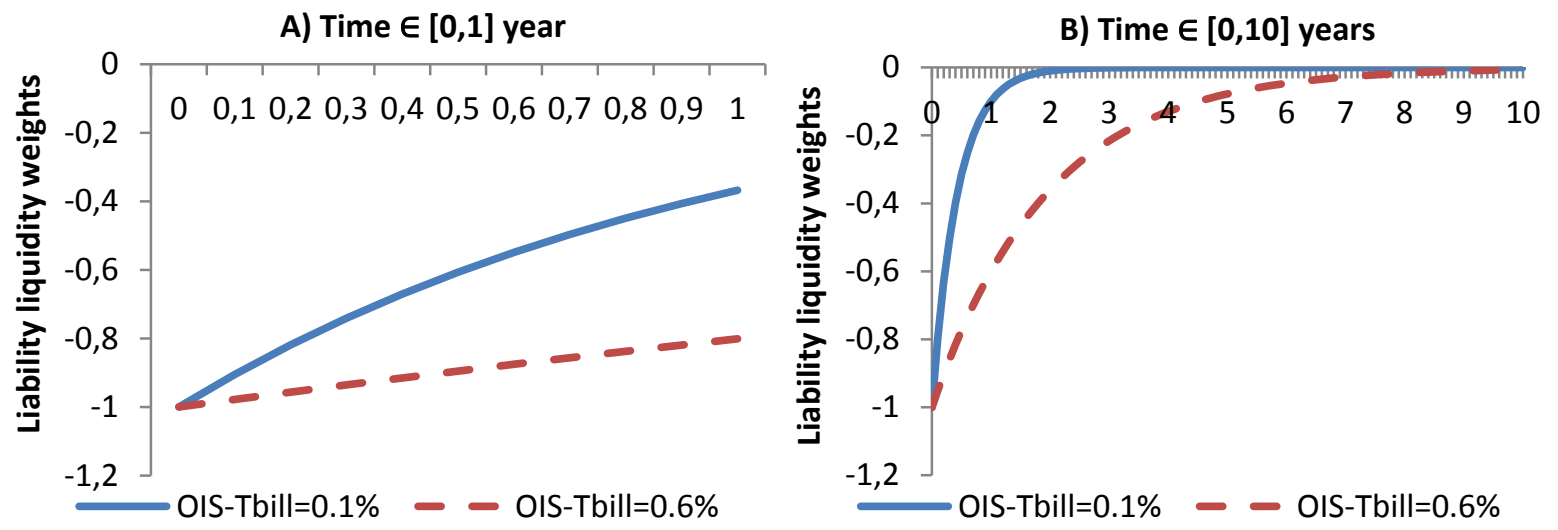

Note: Liability weights $\lambda_{t, l_{k \prime}}=-\exp \left(\ln (\mathrm{OIS}-\mathrm{TBill}) T_{k^{\prime}}\right)$ when OIS-German Tbill is equal to 0.1 (solid line) and when it's equal to 0.6 (dotted line).

\footnotetext{
${ }^{6}$ Indeed, when the market's desire for liquidity is high, as reflected in high OIS German T-Bill spread, financial intermediaries that can issue a liquid liability can earn a premium on this liquidity. Nagel (2016) shows that there is a positive relation between the liquidity premium on bank liabilities and market measures of liquidity premium.

${ }^{7}$ Bai et al. (2018) incorporate an additional parameter, $\mathrm{k}$, that scales the relation between expected stress duration and the OIS-Tbill spread. We keep $k=1$ for the sake of simplicity.
} 
The parameter $T_{k^{\prime}}$ indicates the maturity of a liability of a class $k^{\prime}$. The balance sheet data that we obtain from Bloomberg allow us to distinguish the following classes of bank liabilities: deposits, short-term borrowing, long-term borrowing, other liabilities, equity, and off-balance items. The maturity structure of long-term and short-term debt for each bank is taken from Bloomberg. For other liability classes, we use the calibrated maturities in a spirit of Bai et al. (2018). In particular, deposits have a maturity of five years $(T=5)$, equity of thirty years $(T=30)$, other liabilities of seven years $(T=7)$ and off-balance positions of five years $(T=5)$.

\subsection{Data}

Our data cover the period from 2011:Q1 to 2015:Q3 for a sample of eight French banks that represent around $87 \%$ of the country's banking system total assets. The period covered encompasses the funding stress of 2011 that hit European banks, and the subsequent improvement in funding conditions following the implementation of Longer-Term Refinancing Operations. The period 20132015 also provides an example of a relatively benign period in terms of funding conditions, in contrast to the preceding stress period.

We use confidential data on the pool of eligible collateral in the ECB OMO. These data contain the following information: operation date (weekly OMO), ISIN code of the asset mobilized as collateral, the nominal value of the asset, the value before and after the ECB haircut and the identity of the borrower. We use this database to calculate the haircuts on banks' loans and investment assets. The information on sovereign bonds haircuts comes from the ECB website. LCH S.A. provided us with quarterly time series of private haircuts on sovereign bonds of different maturities and country of issuance.

EBA data from 2011:9, 2011:12, 2012:6 and 2014:01 served, when available, to derive sovereign debt holdings (by maturity and country of issuance) at the bank level. The other relevant balance sheet data - including the maturity structure of the banks liabilities - that we use is obtained from Bloomberg and is available on quarterly, semi-annual or annual bases since 2011. Finally, the OISGerman T-Bill spread is obtained from Bloomberg.

\section{LMI for the French banking sector: the role of the ECB}

\subsection{Evolution of the public LMI between 2011 and 2015}

We calculate the index for individual French banks in our sample and then aggregate it for the whole banking system. When the aggregate public LMI is low, the banking sector is more susceptible to a liquidity stress. It gives the cash equivalent value of the French banking sector and if the index becomes negative, it indicates the amount of the liquidity support that the official authorities might have to provide in case of financial crisis. The LMI can also help identify the individual French 
institutions that are fragile in terms of their liquidity exposures. The evolution of the banking system's liquidity mismatch over 2011-2015 is displayed on Chart 3a (in millions of euros) and Chart $3 \mathrm{~b}$ (scaled by total bank assets). It provides a number of policy-relevant results.

First, the French banking system was still afloat prior to the 2011 central bank interventions. It is in the second half of 2011 that the liquidity mismatch for the system as a whole shows a drastic decline, suggesting a rapid worsening in systemic vulnerability following the stress episodes at the beginning of the year (Chart 3a). Yet, our LMI indicator never falls in negative territory, which demonstrates the resilience of the sector, in aggregate, to deteriorating funding conditions both on the asset and liability side. During the period that precedes the intervention of the central bank, the LMI varied between $18 \%$ and $70 \%$ of total assets. This in turn suggests that, in aggregate, the French banking sector has remained fairly resilient to the 2011 liquidity shock, or at least its immediate impact, even prior to the central bank interventions.

\section{Chart 3: Liquidity mismatch (LMI) of the French banking system}

(a) Liquidity Mismatch Index

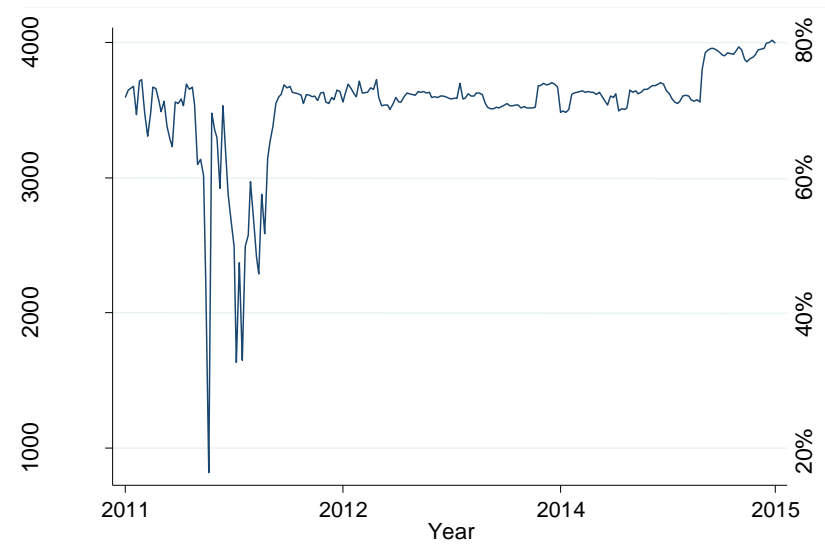

(b) LMI scaled by total bank assets

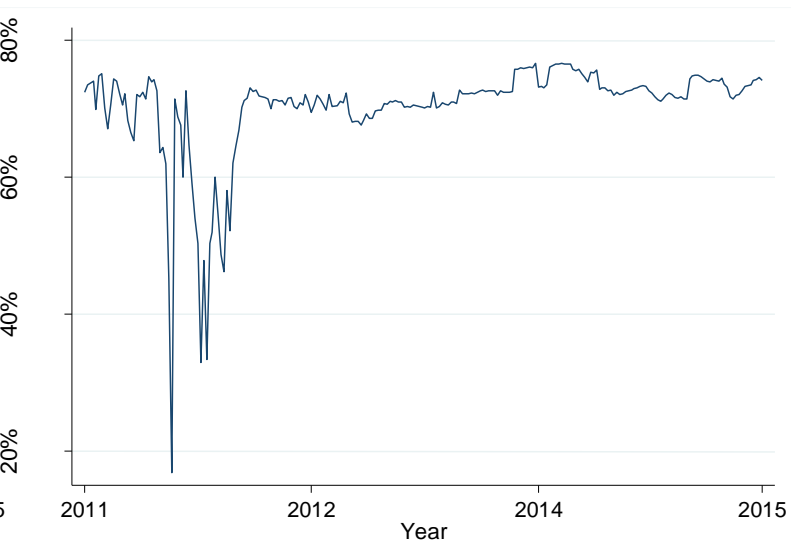

Note: Aggregate LMI in billions of euros (a) and scaled by total bank assets (b). A decrease in the LMI depicts a deterioration of the liquidity situation of the sector, i.e., an increase in the liquidity mismatch between assets and liabilities.

Second, the resilience of the system taken as a whole hides heterogeneity across counterparties (Chart 4). Some banks exhibit a lower LMI throughout the period and one bank stands out as an outlier, experiencing a dramatic fall of its LMI in 2011, to a very negative level, with a strong subsequent recovery bringing its LMI in line with that of the bulk of the sample, around $70 \%$ of total assets. This outlier bank is not large enough to drive the aggregated LMI for all banks into negative territory, but demonstrates that the sector-level resilience does not imply that every bank would have coped with the liquidity stress on a stand-alone basis. 


\section{Chart 4: Heterogeneous dynamics of individual liquidity mismatch}

(a) LMI scaled by total bank assets

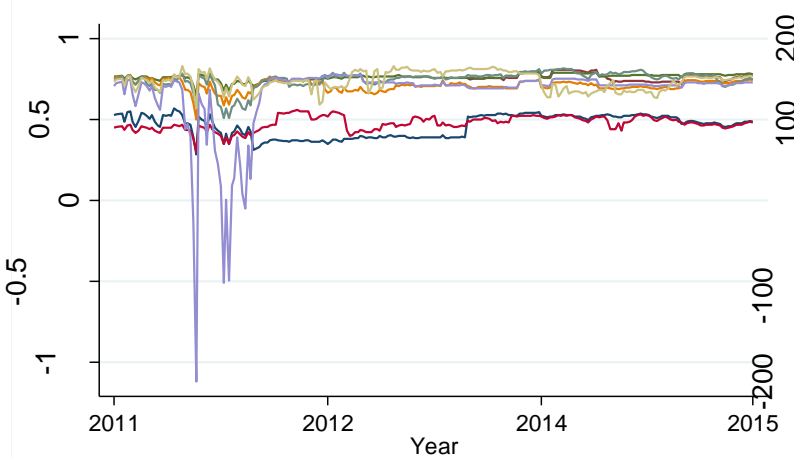

(b) Rebased (2011:Q1=100)

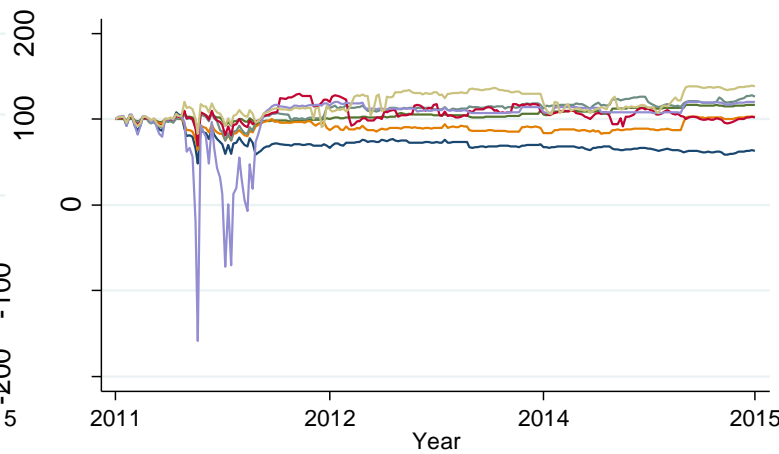
LMI Bank 1
LMI Bank 2
LMI Bank 3
LMI Bank 4
LMI Bank 5
LMI Bank 8
LMI Bank 6

Note: Individual LMIs for eight banks in our sample scaled by total bank assets (a) and rebased at 100 in 2011:Q1 (b).

Third, the deterioration of liquidity proves very gradual and inertial. The speedy decline in the LMI in the second half of 2011 occurs in just one or two weeks, while the return to the initial pre-shock liquidity situation takes as long as 6 months. This asymmetry between the pace of the fall and that of the rebound illustrates the vulnerability of banks to liquidity shocks and the necessity of a credible central bank backstop.

Fourth, the LMI goes back slowly to its pre-fall level from the end of July 2011 until the beginning of February 2012. This period coincides with numerous ECB unconventional monetary policies, namely the restart of sovereign bond purchases in August 2011, the announcement of the covered bond purchase program in October 2011 along with additional one-year LTROs and finally the announcement of three-year LTROS in December 2011. Moreover, the collateral requirements were relaxed in September and December 2011 and then again in February 2012. ${ }^{8}$ The recovery of the LMI during this period suggests the ECB measures played an important role in allowing the bank liquidity mismatch to ease.

Finally, the aggregated LMI of all banks in absolute terms stands at a higher level at the end of the period than before the 2011 liquidity shock (Chart 3a). Most importantly, the aggregated LMI increases notably towards the end of the period, starting in end 2014, and manages to exceed its initial level. This could reflect the impact of the planned implementation of the liquidity regulation, and in particular the Liquidity Coverage Ratio, which observation period was scheduled to start in

\footnotetext{
${ }^{8}$ Barthélemy et al. (2018) find that the ECB collateral expansions covering marketable assets increased the total value of collateral posted by the euro area credit institutions by 70 billion euros. Moreover, the additional credit claims allowed as collateral in December 2011 further improved banks' access to the ECB money by 85 billion euros.
} 
2015. The end-of-period increase is less pronounced when the aggregated LMI is scaled to total assets, perhaps reflecting that the improvement in the liquidity position in euro terms in was used by banks to originate additional (less liquid) lending, which in turn translated into a stable LMI in percentage of total assets.

\subsection{ECB liquidity support: public vs private LMI}

The liquidity mismatch described in the previous section is based on the ECB haircuts. Here, we compare it with the private LMI based on private markets haircuts provided by LCH S.A., which is one of the main central clearing counterparties in Europe. ${ }^{9}$ In this private LMI we use the quarterly LCH haircuts for sovereign bonds according to their maturity and country of issuance. We also account for the possibility that bank loans cannot be posted as collateral in private repo markets while they can be used as collateral at the OMOs of the ECB. An asset that is not accepted as collateral should be assigned a $100 \%$ haircut to account for its ineligibility. Nevertheless, there exists a small possibility to sell them on a secondary loan market so we attribute a haircut equal to $90 \%$ to all loans. Sensitivity analysis on that haircut value would provide a good proxy for the desirability of developing secondary markets for loan portfolios, an issue of great importance for policy discussions around how to deal with so called "bank legacy assets". Finally, we consider the possibility that banks cannot use their investment securities other than sovereign bonds at the ECB OMOs, and must pledge them in private repo markets. However, some of the investment securities eligible as collateral by the ECB is not accepted in private markets, and if they are, higher haircuts are applied. For instance, $\mathrm{LCH}$ accepts government securities and limited MBS and Agency securities ${ }^{10}$ but does not accept corporate or covered bonds. Eurex on the other hand accepts bank and corporate bonds as well as equity and ETF as collateral. Armakola et al. (2017) report that sovereign bonds are the prime collateral for private repo transactions. ${ }^{11}$ Therefore, to account for the possibility of not having access to the ECB OMO, we multiply the ECB haircut for investment securities other than sovereign bonds by 1.5. Chart 5 a shows the evolution of public LMI together with two versions of private LMI: (i) one that considers private haircuts only for sovereign bonds (Market Haircuts - sovereigns), and (ii) one that supposes that loans and all investment securities cannot be pledged at ECB OMO (Market Haircuts - securities \& loans). Both private LMI are lower than their public counterpart, suggesting again that the ECB collateral and haircut policies have indeed alleviated bank liquidity mismatch. If banks had been subject exclusively to - higher - private haircuts it would have reduced their liquidity in a similar way as, for example, a deposit withdrawal. It could even lead to fire-sales of assets in time of financial stress. The liquidity mismatch is more pronounced when not only sovereign bonds but also loans and other investment securities cannot be pledged at the ECB OMO. As such, the

\footnotetext{
${ }^{9}$ Euro repos are mainly bilateral and according to the Euro Money Market Survey 2015 (ECB), the share of centrally cleared secured operations remained broadly stable, at $72 \%$ of all bilateral repo transactions.

${ }^{10}$ US MBS: GNMA; EUR Agencies: KFW and FMSWER; US Agencies: FNMA, FHLMC and FHLB.

${ }^{11}$ ICMA (2017) reports that the share of government bonds within the pool of EU-originated fixed-income collateral accounted for $87.6 \%$ of the survey.
} 
difference between public and private LMIs represents a solid proxy for the ECB liquidity support to the French banking system. In 2012, it approached $€ 800$ billion (Chart 5b).

\section{Chart 5: Public LMI compared to private LMI}

(a) Public and Private LMI

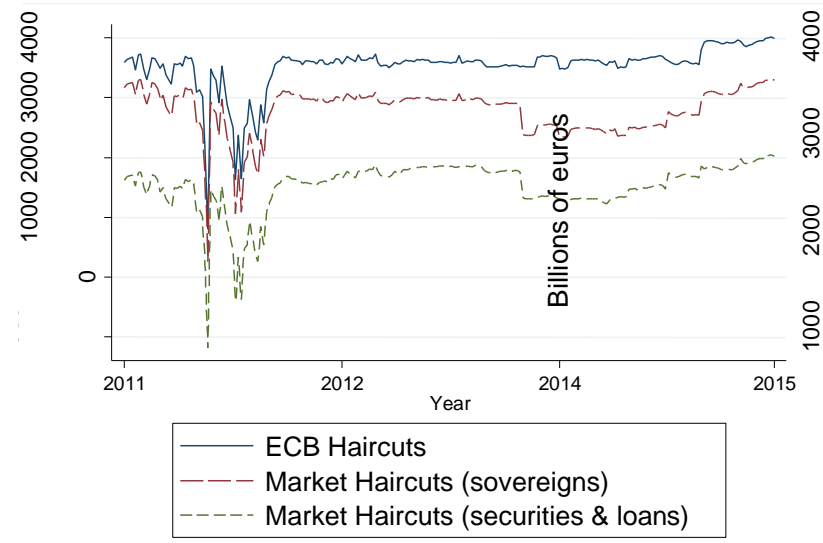

(b) ECB's liquidity support to French banks

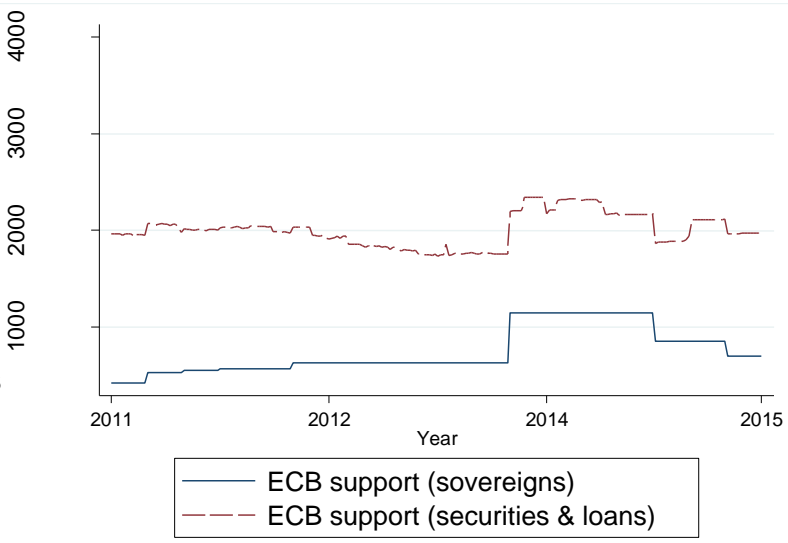

Note: (a) Public LMI (ECB Haircuts) compared to two Private LMI: market haircuts applied to sovereign bonds, and to all investment securities and loans. (b) Two measures of the ECB liquidity support: the difference between Public LMI and two Private LMIs depicted in panel (a).

\subsection{Time-varying vs constant liquidity weights}

Liquidity mismatches can be driven by changes in haircuts (asset-side liquidity weights), OIS-German Tbill spread (liability-side liquidity weights) and bank balance sheet evolutions. Chart 6a depicts liquidity-weighted assets and liabilities divided respectively by the total assets and liabilities. It presents the respective contribution of haircuts and funding liquidity conditions to the LMI evolution. While both asset-side and liability-side liquidity weights contribute to the LMI variations, the liability side is a main LMI driver during the 2011 liquidity stress. This is due to the dynamic setting of our LMI and the time-varying probability that the stress episode continues for a given period of time. This approach allows to account for the liabilities of different maturities as well as the time-varying state of liquidity conditions (Bai et al. 2018). With this respect LMI differs from Berger and Bouwman (2009)'s measure of bank liquidity creation. Berger and Bouwman (2009) also attribute liquidity weights to different asset and liabilities categories but their liquidity weights are constant across normal and crises periods whereas here, they are changing in time. Chart $6 \mathrm{~b}$ compares our LMI computed with time-varying weights to the LMI computed with constant liquidity weights. More precisely, we consider the constant liquidity stress horizon by taking the average of OIS-German T-bill spread either in normal times (average in 2013) or in crisis times (average in October 2011). Chart 6b shows that allowing the liability liquidity weights to vary improves the performance of the LMI. The LMI declines rapidly during the financial stress in 2011 and then goes back to its value before the stress. LMI with constant liquidity stress horizon measured in normal times is higher and does not reflect the liquidity tensions that appeared in autumn 2011 in the euro zone. LMI with liquidity 
weights measured in stressed times also remains relatively stable across the whole period but at much lower level.

\section{Chart 6: Time varying liquidity weights}

(a) Asset-side and Liability-side LMI

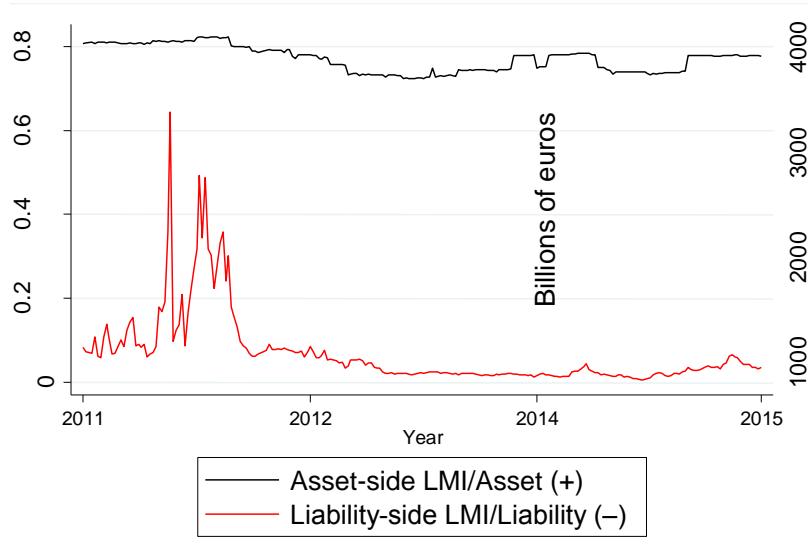

(b) Liability liquidity weights

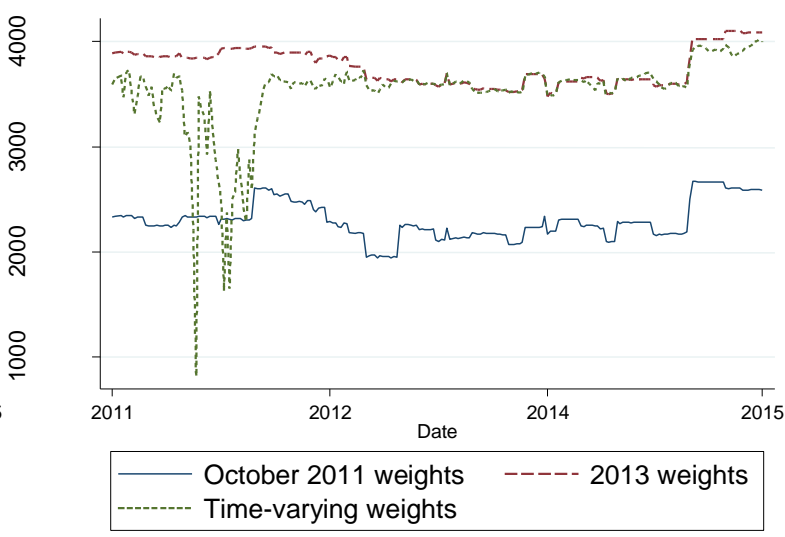

Note: (a) Liquidity-weighted assets (liabilities) divided by total assets (liabilities). Liquidity-weighted liabilities are expressed in absolute values. (b) Time-varying liquidity stress horizon compared to constant liquidity stress horizon, measured in October 2011 (crisis) and in 2013 (normal times).

\subsection{Public LMI as an additional tool to monitor liquidity}

Banks' liquidity exposure is one of the key variables that drive systemic crises and it is essential that supervisors monitor the liquidity position of the financial sector as a whole. If the liquidity risk is not mitigated ex ante by financial regulation and supervision, then central banks and governments must act ex post as lenders of last resort. However, the systemic component of liquidity risk is difficult to measure as liquidity and solvency concerns are very much connected and overlap over a grey area. To address this measurability issue, several liquidity metrics have been recently developed. We argue here that LMI based on the ECB haircut is as an additional tool to monitor banking sector liquidity and complements the indicators of a regulatory nature and those proposed so far by the literature. ${ }^{12}$

\footnotetext{
${ }^{12}$ In addition to papers of Bai et al. (2018) and Berger and Bouwman (2009) that we discussed earlier, there are several other macro-prudential liquidity indicators have been developed to measure systemic component of liquidity risk based both on bank balance sheet items and the market data. Severo (2012)'s Systemic Liquidity Risk indicator assesses systemic liquidity stress level by measuring the breakdown of arbitrage conditions in international financial markets. Under normal conditions, price differentials for similar securities or portfolios tend to be relatively constant and small. However, significant differences in prices between instruments appear during the periods of financial stress and investors do not exploit them for relatively long periods. The magnitude of these non-exploited differences can be interpreted as indicators of stress in securities and funding markets. Jobst (2014)'s Systemic Risk-adjusted Liquidity model combines option pricing with market information and balance sheet data to generate a probabilistic measure of the frequency and severity of multiple institutions experiencing a joint liquidity event, such as the one where banks jointly breach their NSFR ratio.
} 
Basel III acknowledges the importance of liquidity by imposing liquidity ratios known as the Liquidity Coverage Ratio (LCR) ${ }^{13}$ and Net Stable Funding Ratio (NSFR) ${ }^{14}$. Such micro-prudential liquidity rules have shortcomings. While high ratios of NSFR and LCR diminish the chance of a systemic liquidity event for an individual institution, they do not prevent the build-up of a systemic liquidity risk. They can even make the whole financial system more risky when all banks have to meet a requirement at the same time (Claessens and Kodres, 2014). The Basel III liquidity ratios do not take into account the impact of a bank's failure on the financial system and are less likely to detect the events that affect multiple institutions simultaneously and might require central bank liquidity support. Thus, systemic rather than bank-centered approach is needed to prevent the initial shock, such as sudden dry-up of asset-backed commercial paper market, from turning into systemic crisis. Finally, current regulations are more aimed at addressing funding liquidity, but are less able to affect market liquidity, which can be an important trigger for collateral runs and fire sales mechanisms.

LMI, contrary to the LCR, does not limit the liquidity horizon to 30 days which is an advantage given that there were many periods in recent years where the liquidity stress lasted for several months. During a financial crisis when the liquidity premium is high, the LMI is computed under a longerlasting liquidity scenario. LCR just as LMI underlines importance of both market and funding liquidity. However, the definition of high quality liquid assets is fixed whereas in reality these assets can quickly become illiquid (Greek government bonds). LMI implements time-varying asset weights (haircuts) which account for the changing market conditions.

Unlike the Basel III micro-prudential measures, the LMI can also be meaningfully aggregated across the whole financial sector and provide an indicative amount of liquidity that the central bank might have to provide in case of a liquidity stress.

\section{Conclusion}

Despite the advances that have been made by the policymakers and the academic literature, the ability of systemic risk measures to signal difficulties much ahead of the liquidity stress is still relatively untested. In this paper we present a liquidity measure for the French banking system that incorporates the ideas from the academic literature on liquidity. LMI jointly accounts for asset and liability liquidity conditional on the state of market liquidity. We construct the LMI for the French banking sector and show that despite a rapid worsening in systemic vulnerability following the stress

\footnotetext{
${ }^{13} \mathrm{LCR}=$ high-quality liquid assets/(cash outflows -cash inflows) at 30 days $\geq 100 \%$. Assets are considered to be high-quality liquid if they can be easily and immediately converted into cash at little or no loss of value. There are three categories of high-quality liquid assets which under Basel III are subject to different haircuts: level 1 assets have no haircut, while level $2 \mathrm{~A}$ and level $2 \mathrm{~B}$ assets have a $15 \%$ and $50 \%$ haircut, respectively.

${ }^{14}$ NSFR = available amount of stable funding/required amount of stable funding $\geq 100 \%$. "Available stable funding" is the portion of capital and liabilities expected to be reliable over a one-year horizon. "Required amount of stable funding" for a specific institution is a function of the liquidity characteristics and residual maturities of the various assets held by that institution as well as those of its off-balance sheet exposures.
} 
episodes in 2011, the LMI never falls in negative territory, which demonstrates the resilience of the sector in aggregate. However, the resilience of the system taken as a whole hides heterogeneity across counterparties. Some individual banks exhibited tangible liquidity mismatch and there is no guarantee that these would not have led to systemic issues, absent ECB intervention.

This paper highlights the influence of the ECB on bank liquidity mismatch. In particular, the ECB haircut and collateral eligibility policies have provided measurable support to French banks' liquidity. This is evident when comparing the public LMI based on ECB haircuts with that based on haircuts applied to private repo transactions. Our analysis suggests that the ECB has alleviated banks' liquidity mismatch significantly between 2011 and 2015.

What can be the usefulness of an indicator such as the LMI for policy purposes? Relative to existing tools, the LMI has a dual advantage as a real-time monitoring tool of bank liquidity conditions. It combines quantity-based measures (balance sheet items) and price-based measures (haircuts; spreads), while existing indicators are based either on prices or on quantities, but rarely both. In addition, it can be computed at a weekly frequency, allowing for a fairly high frequency monitoring relative to pure balance sheet based approaches. Therefore, the LMI could constitute a useful addition to the toolbox of market analysts, risk managers and central banks, in their assessment of banking system liquidity risk. An additional usefulness of the LMI is for stress-testing. The LMI could lend itself to stress testing approaches, for instance by applying a shock to the level of market haircuts or by assuming a sudden shortening of the maturity of liabilities. 


\section{References}

Armakola, A., R. Douady, J.-P. Laurent, and F. Molteni. 2017. "Repurchase agreements and systemic risk in the European sovereign debt crises: the role of European clearing houses." Université Paris1 Panthéon-Sorbonne (Post-Print and Working Papers).

Bai, J., A. Krishnamurthy, and C.-H. Weymuller. 2018. "Measuring the liquidity mismatch in the banking sector." Journal of Finance, Volume 73, Issue 1, Pages 51-93.

Barthélemy, J., V. Bignon, and B. Nguyen. 2018. "Monetary policy and collateral constraints since the European debt crisis." Banque de France Working Paper, forthcoming.

Berger, A. N., and C. H. S. Bouwman. 2009. "Bank Liquidity Creation." Review of Financial Studies, Society for Financial Studies, Volume 22(9), Pages 3779-3837, September.

Berger, A. N., and C. H.S. Bouwman. 2017. "Bank liquidity creation, monetary policy, and financial crises." Journal of Financial Stability, Volume 30, Pages 139-155.

Bindseil, U., M. Corsi, B. Sahel, and A. Visser. 2017. "The Eurosystem Collateral Framework

Explained." ECB Occasional Paper No. 189, May.

Brunnermeier, M. K., G. Gorton, and A. Krishnamurthy. 2011. "Risk Topography", NBER Chapters, in: NBER Macroeconomics Annual 2011, Volume 26, Pages 149-176, NBER, Inc.

Claessens, S., and L. E. Kodres. 2014. "The Regulatory Responses to the Global Financial Crisis; Some Uncomfortable Questions." IMF Working Papers 14/46, International Monetary Fund.

Ewerhart, C., and N. Valla. 2007. "Forced Portfolio Liquidation." Working papers 179, Banque de France.

ICMA. 2017. European Repo Market Survey, International Capital Market Association, $n^{\circ} 33$, October.

Jobst, A. 2014. "Measuring systemic risk-adjusted liquidity (SRL)-A model approach." Journal of Banking \& Finance, Elsevier, vol. 45(C), pages 270-287.

Marx, M., B. Nguyen, and J.-G. Sahuc. 2016. "Monetary policy measures in the euro area and their effects since 2014." Rue de la Banque, Banque de France, issue 32, October.

Nagel, S. 2016. "The Liquidity Premium of Near-Money Assets", Quarterly Journal of Economics, 131, (4), 1927-1971.

Severo, T. 2012. "Measuring Systemic Liquidity Risk and the Cost of Liquidity Insurance." IMF Working Papers 12/194, International Monetary Fund.

Szczerbowicz, U. 2015. "The ECB Unconventional Monetary Policies: Have They Lowered Market Borrowing Costs for Banks and Governments?" International Journal of Central Banking, vol. 11(4), pages 91-127, December. 